\title{
Reconstructing Chineseness: Chinese Media and Chinese Identity in Post-Reform Indonesia
}

\author{
SETEFANUS SUPRAJITNO \\ Petra Christian University, Jln. Siwalankerto 121-131, Surabaya, Indonesia \\ steph@petra.ac.id
}

Published online: 15 April 2020

To cite this article: Setefanus Suprajitno. 2020. Reconstructing Chineseness: Chinese media and Chinese identity in post-reform Indonesia. KEMANUSIAAN the Asian Journal of Humanities 27(1): 1-23. https://doi.org/10.21315/kajh2020.27.1.1

To link to this article: https://doi.org/10.21315/kajh2020.27.1.1

\begin{abstract}
The fall of Suharto in 1998 brought winds of change to Indonesia, especially to policies concerning the Chinese. After being suppressed under the Suharto regime, Chinese Indonesians suddenly had an opportunity to express their cultural heritage in their own ethnic media, counter negative stereotypes and reconstruct an identity that had been virtually erased during the Suharto era. In this article, author examines the discursive practices Chinese Indonesians use to remould their ethnic identity through an analysis of the media strategies used to reinvigorate the Chinese Indonesian identity. It was found from the Chinese media, as exemplified in Qiandao Ribao, Guoji Ribao and Yindunixiya Shangbao, that the re-creation of the Chinese identity requires an understanding of what it was to be Chinese through the use of the symbols most salient to Chinese ethnicity. The media have been strongly geared towards the reconstruction and maintenance of a Chinese identity that sees Chinese Indonesians as an imagined community whose ethnicity is symbolically perceived and maintained through frequent exposure to the ethnic media. By being exposed to the ethnic media, Chinese Indonesian readers can feel a sense of ethnic belonging and identity through perceived affiliation and shared symbols. However, although they succeeded in bringing Chinese culture back to the Indonesian public sphere, the diversity in the Chinese community challenges the media efforts to construct a definitive Chinese identity.
\end{abstract}

Keywords and phrases: Chineseness, Chinese Indonesian, identity, media, post-reform Indonesia

\section{Introduction}

Up until 1965, there had been several Chinese newspapers in Indonesia. However, when the Suharto regime was in power (1966-1988), a period described as "the dark ages for the Chinese press" (Hoon 2006, 96), all Chinese media except 
the military backed Yindunixiya Ribao was banned. Suharto's downfall in 1998 brought a change to the political landscape and gave the Chinese media a new lease of life. "The Chinese-Indonesian press can finally welcome the light of the morning sun", claimed Huang Hui (as quoted in Hoon 2006, 97). Being finally allowed greater freedom of expression, the Chinese media was able to once again target the Chinese community as the potential readers of their publication in both Chinese and Indonesian. Its purpose was reconstructing its readers' Chinese ethnic identity which experienced erasure due to Suharto's policies. Since that time, Chinese dailies, weeklies, magazines and tabloids have proliferated.

A number of new Chinese-language and Indonesian-language Chinese newspapers and magazines emerged in 1998 such as Qiandao Ribao, Yindunixiya Shangbao, Guoji Ribao and Chinatown. However, several others have ceased publication, such as Longyang Ribao, Huawen Youbao, Yinhua Tiansheng and Sinergi Indonesia because they failed "to understand their potential readership and the contemporary Chinese community itself" (Pandiangan 2003, 419). Overall, the Chinese media in Indonesia has limited readership, primarily because few Chinese Indonesians and especially the younger generation, are able to understand Chinese (Hoon 2006; Lie 2017). In Lie's opinion, their inability to understand Chinese occurs because "younger Chinese Indonesians were publicly deprived of the opportunity to maintain their cultural heritage during the Suharto administration" (Lie 2017, 47). Therefore, to increase readership has been a significant challenge, as claimed by Sugondo Margonoto, a Chinese businessman who had supported the publication of Qiandao Ribao's, at the newspaper's 10th anniversary:

It has been ten years since Qiandao Ribao was published. The founding fathers pledge to continue publishing this newspaper although it has suffered financial losses all these years... It is impossible for a Chinese newspaper to gain a profit. However, we are willing to cover the financial losses because we believe that we should keep on publishing our newspaper because it has an important mission; namely, to preserve the Chinese language and culture in Indonesia [author's translation; italics added]. (Qiandao Ribao 2010, 13)

Margonoto's statement highlighted the cultural mission of not only Qiandao Ribao but all other Chinese media; a mission that has become the impetus for their survival.

In spite of the limited readership, the Chinese media's will to survive is so that Chinese Indonesians can "develop visions of their futures in Indonesia" (Turner and Allen 2007, 120) and provide an avenue to express themselves to regain the 
ethnicity that had been banned during the New Order regime. Previous studies have found that there is a strong connection between ethnic media and the perceptions of ethnic identity. For examples, Matsaganis (2011), Oh (2016) and Somani and Guo (2018), found that ethnic media encourages communication within the ethnic community by giving them a voice, expressing their concerns, advancing and defending their interests and interpreting issues from the community's perspectives, all of which develops and fosters ethnic belonging and preserves a cultural consciousness and an ethnic identity.

Along with the freedom to celebrate their ethnicity, the post-Suharto Chinese media was also able to express the community's concerns by protesting against discrimination, preserving language and culture, and making people aware of the issues in their ethnic community. All of this was made possible because the people behind the post-Suharto Chinese media had been involved in the Chinese media in the pre-Suharto era. The Chinese media re-emerged into the "public sphere" (Habermas 1991) to provide a communicative space to a people "who had been silenced over the three previous decades, to speak out" (Hoon 2006, 91). Therefore, the Chinese media views its role as preserving Chinese culture and encouraging Chinese Indonesians to embrace the ethnic identity that was suppressed during the New Order era. However, in its efforts to do so, the Chinese media overlooks the heterogeneity of Chinese Indonesians.

The ethnic Chinese in Indonesia is a diverse entity. Its diversity is due to, among others, economic background, culture and political orientation. Culturally, the Chinese in Indonesia could be categorised into two groups. One was totok Chinese, referring to the Chinese who were "pure" and still culturally Chinese in the sense that they maintained their Chinese heritage, such as language and had Chinese cultural orientation. The other was called peranakan Chinese, referring to the Chinese who were of mixed descent and assimilated, had cultural orientation towards local cultures and spoke local languages. Peranakan Chinese who went to Chinese school before it was banned may speak Chinese, but Chinese was not their first language. Today, the distinction between totok and peranakan Chinese has blurred. Nevertheless, the diversity of Chinese Indonesians, especially in terms of cultural orientation, remains.

This article investigates how Chinese media reconstructs the ethnicity of Chinese Indonesians. In doing so, this article examines the discursive practices used in the ethnic media to develop the ethnic and social identity of the Chinese community. Through an analysis of news reports, this article examines the strategies used in the Chinese press to reconstruct the Chinese identity. 


\section{Conceptual Framework for Ethnicity and the Media}

Since Barth (1969) proposed the conception of ethnicity as a social process in 1969 , there has been wide research focused on the notion of ethnicity, with some such as Bayar (2009), Eriksen (2010), Fenton (2010) and Bowen (2017) concurring with Barth. Today, ethnicity is no longer seen as immutable or as a fixed entity; rather, it is seen as fluid as it is situationally defined in the social interactions with other groups as well as by the boundaries it establishes and maintains as a result of these interactions. Kivisto claimed that "ethnicity is essentially a social boundary" (Bowen 2017, 1426), with these boundaries being mental and cultural rather than physical and being more important than the culture they enclose. Ethnic boundaries are constituted by selected cultural features that the members ascribe to themselves and consider relevant; in other words, the cultural features that are "perceived as typical for their community" (Wimmer 2008, 973) and can "reinforce their collective identity" (Smajda and Gerteis 2012, 619). Therefore, ethnicity is more related to the emotional significance attached to the cultural content rather than the cultural content itself.

In an effort to establish and maintain ethnic boundaries, ethnic groups attempt to sustain their feelings of identity and of being ethnic. The continuity of these feelings, which Cornell $(1996,268)$ called "ethnic persistence", is important as it gives the members ethnicity and identity, which in turn gives them a sense of belonging and social existence. Weeks claimed that "identity is about belonging, about what you have in common with some people and what differentiates you from others" $(1990,88)$. Therefore, ethnic persistence is related to the specific features of the ethnic group that engender a sense of belonging and distinguish them from others.

Ethnicity is strongly related to group belonging, self-identification and identification by others outside the group, the perception and expression of which is often expressed through symbolic means. Gans $(2017,1411)$ claimed that, "In effect, feeling ethnic is achieved by employing ethnic objects, material and nonmaterial, as well as symbols". Rather than knowledge or practice, what is of importance are the feelings of ethnic identity because "identities are about questions of using the resources of history, language and culture in the process of becoming rather than being: not 'who we are' or 'where we came from', so much as what we become, how we have been represented and how that bears on how we represent ourselves" (Hall 1996, 4). Therefore, ethnic identity comes from a self-narrative associated with an imagined belonging to a certain group of people who draw attention to the shared culture that binds them into what Anderson (2006) called an "imagined community". 
When forming this imagined community, group members use ethnic symbols rather than specific cultural practices. Gans stated that the logic of modern ethnicity is based on symbols and feelings of identity. In his opinion, ethnicity is symbolic as people "move from acting to feeling ethnic, which emphasises identity instead of practising the culture and participating in its organisations" (Gans 2017, 1411). Because feelings of identity and expressions of those feelings are the primary ways of being ethnic, ethnicity depends largely on the use of symbols, which become the ethnic group identity markers used to establish and maintain the ethnic boundaries that define the imagined community; in other words, as stated by Gans, ethnicity is symbolic.

However, the characteristics of symbolic ethnicity are arbitrary. Depending on the situation and on how important they feel their ethnicity is, individual ethnic group members may have different ways of perceiving and expressing their ethnic symbols. This has been identified as "ethnic salience", which is defined as "the importance that individuals attach to ethnicity" (Bhavnani and Miodownik 2009, 30). Therefore, ethnic salience has a close relationship with ethnic persistence as the former embodies the notions of the latter. Generally, there is a hierarchy of ethnic salience, with ethnic group members valuing some aspects of their ethnicity more than others, with these aspects being more important to their ethnic persistence; in other words, these valued aspects create the feelings of identity and of being ethnic and basically function as ethnic identifiers.

Ethnic salience reinforces ethnic persistence, which then maintains the ethnic boundaries that define the imagined community. Anderson $(2006,6)$ believes that "communities are to be distinguished, not by their falsity/genuineness, but by the style in which they are imagined". In other words, it is the "forms of imagining" that construct a community (Anderson 2006, 24).

In their construction of the imagined community, "print-capitalism" (Anderson 2006, 18) - magazines and newspapers - allows groups to "imagine" a linked community that may not have had any special forms of togetherness. The imagined linkages that the media engenders, in Anderson's opinion, "derive from two obliquely related sources". The first is what he calls "calendrical coincidence" (Anderson 2006, 33), which refers to events that occur at various places on the same date; in other words, readers anonymously share what they read with other readers which makes them feel they belong to a collective body of readers. The second is the media creates what Anderson $(2006,35)$ calls "mass ceremony" in that the readers are participating in a consumption of media and although this consumption "is performed in silent privacy", the readers know that "the ceremony" they are performing is also being simultaneously performed by "thousands (or millions) 
of others of whose existence [they are] confident, yet whose identity [they have] not the slightest notion" (Anderson 2006, 35). This enables them to feel part of the community of readers/audience with whom they have no direct interactions. Calendrical coincidence and mass ceremony are important in the development of the collective identity for members of this imagined community.

Cohen (1985) also claimed that the construction of a community is symbolic. In his opinion, the idea of a community is "symbolic, rather than a structural construct" (Cohen 1985, 98), as the core of community consciousness is a feeling of belonging and identity as well as a sense of distinction, which generally operates through symbols and representations (Cohen 1985, 15).

Therefore, the media plays a constitutive role in the creation of the symbols and representations that heighten the sense of community. According to Appadurai, the media constructs collective imaginations within the public spheres of a community. However, imagining is not equal to fantasising; rather, it has the capacity of agency. Appadurai $(1996,7)$ claimed, "It is the imagination, in its collective forms, that creates ideas of neighbourhood and nationhood... The imagination is today a staging ground for action and not only for escape". The collective imaginations and experiences the media provides, which are formed as a result of their discursive practices, have the ability to rouse agency, to create solidarity and to develop a staging ground for actions, all of which are advanced by the existence of the public sphere, which is "a domain of our social life in which such a thing as public opinion can be formed" (Habermas 1991, 399). Habermas' public sphere is seen as a social realm in which public discourse, such as ethnicity, can be circulated and debated and allows the ethnic media to give its views. In Yu's words, the public sphere provides a platform where ethnic minorities have "the right to communicate" and "a right to be understood" (Yu 2018, 1979). Hence, it is through the public sphere that the ethnic media can overcome sociocultural marginalisation, counter negative representations and maintain and elevate their ethnic identity.

Grounded in this conceptual framework that ethnicity is a mental construct of an imagined community in which the boundaries are symbolically created through ethnic salience and persistence, the media facilitates the creation of the symbols and representations through the public sphere that forge identity; therefore, the role of the Chinese media is to reconstruct the Chinese identity of Chinese Indonesians.

\section{Methodology}

The data for this article were collected primarily through analysing news reports and coverage on categories that are closely related to Chinese ethnicity. 
Those categories are (1) Chinese rituals, traditions and culture, (2) Chinese language, (3) Chinese organisations, (4) Chinese pop culture and (5) the Chinese diasporic community. News reports and coverage chosen for analysis were those issued since March 2017. News reports and coverage from Qiandao Ribao, Guoji Ribao and Yindunixiya Shangbao, the Chinese language newspapers that have survived to the present day and circulated nationally were chosen. Interviews were also held with Chinese media practitioners and regular and non-regular readers of Chinese media in order to get a better understanding on the strategies being used in the media and readers' perception on those strategies. Media practitioners selected for the interviews were editors and journalists of Chinese media. One chief editor, two editors and four journalists were willing to be interviewed. The result of the interviews with them was used for supporting the news report and coverage analysis, all of which enabled me to understand the role the Chinese media envisioned and played in the reconstruction of Chinese identity. Author also interviewed readers of Chinese media - there were 15 of them, aged 20 to 35 years old - in order to understand how they perceived the media consumed. In order to get diverse perspectives, Chinese Indonesian readers coming from various economic and cultural backgrounds were selected as the interviewees. In terms of social class, 10 interviewees belonged to middle-class and upper-middle-class families and five were from a low-income family background. Four interviewees were college students, two worked as Chinese language instructors, two ran their own businesses and seven were professionals in private companies (banking, financial and trading). In terms of Chinese language use, only seven interviewees said that they were from Chinese-speaking families. However, there were only three of them who admitted that their parents spoke Chinese quite well. The rest said that it was only their grandparents and the generations of their grandparents who spoke Chinese. Most of the time, their parents spoke Indonesian of Javanese, peppered with Chinese words. The other eight interviewees said that Chinese language was not spoken in their families, except Chinese expressions for kinship terms and numbers.

\section{Forms of Imagining}

This analysis of the Chinese Indonesian community as an imagined construct is informed by Gupta's and Ferguson's study (1992), which emphasised the salience of the imagination in the construction of an ethnic community. The imagination construct is basically a feeling of identity and belonging that is derived from an attachment to a shared body of symbols (Anderson 2006; Cohen 1985), which are those aspects that function as differentiating symbols and are indexical to the imagined ethnicity. 
The distinction of Chinese Indonesians as an imagined community comes from a belief in a common ancestry and the sense of identity and group boundaries that are experienced and expressed through the various ethnic culture symbols that represent their ethnic salience. As the Chinese media in Indonesia use these symbols to inculcate a sense of the imagined ethnic community, these symbols can be thought of as "forms of imagining" (Anderson 2006, 24) that mediate between the Chinese Indonesian readers of the ethnic media and their Chinese ethnic identity; in other words, the attachment to these forms maintains the imagined ethnic community. In this part the forms of imagining often appearing in Chinese ethnic media are identified and examined.

The first form of imagining is the development of ethnic institutions since these function as powerful mechanisms for the creation and maintenance of ethnic identity and ethnic boundaries. Driedeger $(1989,160)$ claimed that ethnic institutions correlate with ethnic identity as the more institutionally complete an ethnic community is, the greater the likelihood the retention of ethnic culture and identity. Ethnic organisations can also reinforce the strong sense of ethnic identity (Eriksen 2010, 49). Examples of ethnic institutions in Indonesia are social, political and religious organisations. Through such ethnic institutions, among others, Perhimpunan Indonesia Tionghoa (Chinese Indonesian Association) and Paguyuban Sosial Marga Tionghoa Indonesia (Indonesian Chinese Clans Social Association), the Chinese community attempts to find solutions to the problems Chinese Indonesians face as an ethnic group. They also attempt to retain their ethnic language, customs and cultural practices as well as creating an ethnic awareness that strengthens their ethnic identity, for example, Paguyuban Meizhou Indonesia (Indonesian Meizhou Association) and Perhimpunan Hakka Indonesia (Indonesian Hakka Association). Religious-based Chinese organisations such as Majelis Tinggi Agama Khonghucu Indonesia (MATAKIN) or The Supreme Council of Confucian Religion in Indonesia and Persatuan Islam Tionghoa Indonesia (PITI) or Indonesian Chinese Muslim Association also seek to overcome negative Chinese Indonesian stereotypes through their social development and charitable initiatives, which demonstrate that in spite of their ethnicity, they are also a part of the Indonesian community.

Besides social, political and religious organisations, another important ethnic institution for the Chinese community is Chinese school, seen as one of the three pillars of the Chinese community (Suryadinata 1997, 12). A Chinese scholar, Mona Lohanda claimed that the Chinese community believes that Chinese schools are able to impart Chinese cultural values to the young generation (Kompas, 
2 June 2008), which is why many Chinese organisations have founded Chinese schools since they hope that young Chinese Indonesians can develop an emotional attachment to their ethnic culture and therefore sustain their ethnic identity. Fenton (2010, 73-74) noted that the development of these emotional attachments develops the ethnic cultural consciousness that constitutes ethnicity.

The second form of imagining is related to ethnic traditions, rituals and culture, which are concrete practices that, according to Gans, serve as symbols of ethnicity. Practices such as the celebration of ethnic festivals, traditions and rituals are primary ways of practicing and maintaining ethnicity (Gans 2017, 1411) as they are ritualised symbols that engender a sense of belonging (Driedeger 1989, 161) and an imagined Chinese ethnicity. An example of this is the Chinese New Year, widely reported in the Chinese media. Declared as a national holiday by President Megawati on April 2002, the Chinese New Year celebration is seen as an acceptance of Chinese culture in Indonesia. In spite of their different backgrounds, many Chinese Indonesians see this celebration as a way of celebrating their ethnicity. For example, one famous and historical mosque in Yogyakarta (Syuhada Mosque) held a special prayer session to celebrate Chinese New Year for the first time (Karni, Mulya and Windrawan 2006). Some Catholic churches also held a mass with Chinese New Year nuances (Kompas, 19th February 2007), a tradition which some churches still continue.

Another form of imagining is language since it serves as the fundamental expression of group collective identity and ensures its maintenance. Some scholars, such as Driedeger (1989), feel that language is one of the indicators of ethnic cohesion, arguing that there is a strong correlation between ethnic language retention and the development and reinforcement of ethnic consciousness. Therefore, through the promotion of the Chinese language, the Chinese in Indonesia can regain their ethnicity. A Chinese Indonesian scholar claimed that by mastering the Chinese language, "this [young] generation of Indonesian Chinese does not have to bear the deep sense of cultural loss that members of [her] generation endured during the Suharto era" (Dawis 2007).

Because of their position as a "foreign" ethnic minority, many Chinese Indonesians often view themselves as part of the diaspora; therefore, as a diasporic community, they often identify themselves with a more global Chinese identity. This identification as part of the Chinese diaspora is evident in the last two forms of imagining: an interest in the activities of Chinese diasporic communities and Chinese pop culture. 
The interest shown by the Chinese Indonesian community in the Chinese diaspora strengthens their ethnic identity. Driedeger's $(1989,161)$ study found that a knowledge of and an interest in one's history were important avenues for the symbolic reinforcement of ethnic identity. Therefore, current events in fellow diasporic communities assume symbolic significance for many ethnic group members, which then become the focus of their ethnic orientation and identity. By consuming news about what is happening in other ethnic Chinese communities, the Chinese Indonesian community can share images and feelings, making them feel a part of the large imagined Chinese diasporic community.

Chinese pop culture, such as songs, films and television serials work to maintain the Chinese diasporic community's cultural identification. Gans $(2017,1411)$ noted that "ethnic feelings could be further expressed by celebrating famous coethnics, whether entertainers, athletes, artists, writers and others". Dayan and Katz (1992) observed that the electronic media and particularly television, have the power to create instant histories that become part of the audience's collective memory, traditions and identity. In her study on the Indian community in England, Gillespie (1995) found that Indian films shaped and influenced the collective memories of the "mythic homeland" in the diasporic Indian community. Ma (1999) concurred with Gillespie in his study on Hong Kong television audiences, in which he found that pop culture was very much part of their collective memory and imagination for membership in the Chinese nation-state.

Through the consumption of Chinese pop culture, Chinese Indonesians can also reinvent and renegotiate their Chinese identity and at the same time identify themselves as part of the widely scattered Chinese diasporic community, all of whom also consume the same pop culture. Chua (2006, 87-88) commented that "within this dense traffic of cultural production, circulation and consumption is the potential for the emergence of an imaginable 'pan-Chinese community' that can manifest itself through different channels, modes and communication media".

These forms of imagining - ethnic institution, traditions and rituals, language, as well as interest in fellow diasporic communities and their pop culture-elucidate the Chinese Indonesian community as an imagined community that has a symbolically perceived and expressed ethnicity. As these imaginings create salient symbols of Chinese identity and ethnicity, the Chinese ethnic media harness these symbols in their effort to reconstruct the identity and ethnicity of Chinese Indonesians. 


\section{Vehicle of Imagining}

The analysis shows that the Chinese ethnic media uses the mentioned forms of imagining to develop and stimulate Chineseness in Chinese Indonesians and especially in the younger generations whose ethnicity was reduced or even lost during the New Order period. A senior editor of a Chinese newspaper said,

The openness towards Chinese language and culture inspired us, the old generation, to bring the young Chinese generation back to their roots. One way of doing so is through publishing a newspaper. (Informant, pers. comm., 5th May 2017)

This statement echoed the words Huang Xiaozhong, a senior reporter at Qiandao Ribao, said at the inauguration of Qiandao Ribao's new office on 12th June 2012, "This newspaper was published in memory of our Chinese school teachers and to serve as a learning avenue for young Chinese-Indonesians" [author's translation].

These two statements clearly underscore the main goals of the Chinese ethnic media to provide an index for their ethnic culture, values, norms and traditions. The media content that seeks to illuminate the ethnic symbols fuels the forms of Chinese ethnic imagining and reinforces the sense of belonging in the imagined Chinese community. These forms of imagining are evident in news reports, articles, editorials, opinions and other features as the Chinese media is focused on promoting Chinese culture and highlighting and celebrating Chinese identity.

As mentioned previously, one of the forms of imagining is the ethnic organisation. News reports in the Chinese media often cover the numerous activities of Chinese organisations in their efforts to counter the negative stereotypes of Chinese Indonesians that native Indonesians have such as a lack of loyalty to Indonesia, anti-social behaviour and being merely economic animals (Turner and Allen 2007; Coppel 1983). An example of the activities that news reports often covers is charity. News reports also often reveal the nationalistic face of the Chinese through, for example, the use of Indonesian nationalistic attributes and symbols in the activities conducted by Chinese organisations. The efforts of Chinese organisations to cooperate with various Chinese and non-Chinese elements in the society to participate in building Indonesian society are often reported in the Chinese media. The media also heavily covers Chinese organisations that voice the aspirations of the Chinese community to abolish the discriminatory laws that are still in place (Jusuf 2001) in news reports, feature articles and editorials, with the primary aim of reminding the Chinese of the problems they still face as an ethnic group and also as a reminder of their ethnicity. Yet, at the same time, they also remind them of their position as one of the ethnic groups in the country and the responsibilities 
that come with this position. All the Chinese newspapers have a section entitled Huashe (Chinese Community) or Huashe Xinwen (Chinese Community News), which is devoted to covering the activities of Chinese communities in Indonesia (as shown in Figures 1 to 3).

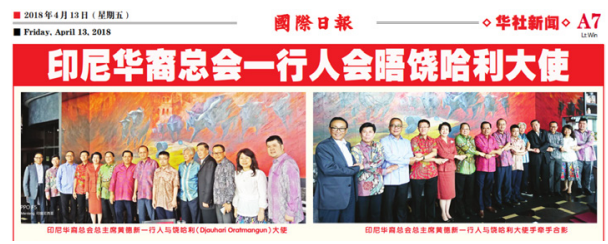

Figure 1. The section Huashe Xinwen in Guoji Ribao: This coverage is about a meeting between Perhimpunan Indonesia Tionghoa (Chinese Indonesian Association) and the Indonesian ambassador to China Source: Guoji Ribao (2018)

印尼萧氏宗亲总会春节团拜晚会 今年承办“第11届环球萧氏宗亲看亲大会”

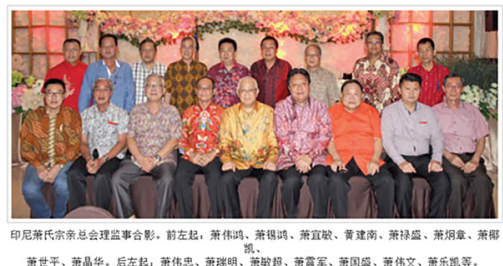

Figure 2. Coverage of the Chinese New Year celebrations of the Xiao clan association in Yindunixiya Shangbao's

Huashe Xinwen

Source: Yindunixiya Shangbao (2018)
祭端午 添寿福 一记泗水广繁会馆举办端午节祭祀活动

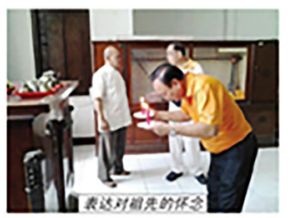

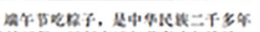

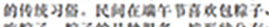

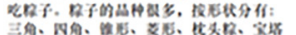

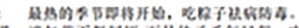
n

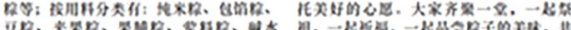

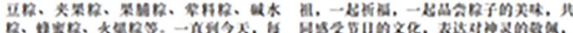

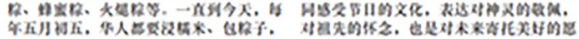

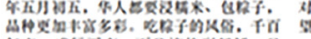

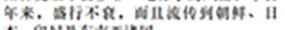

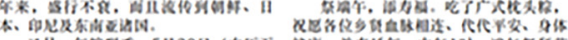

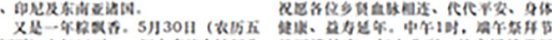
月颃) 上午1

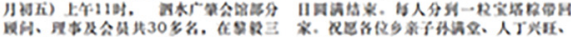

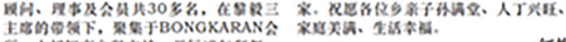

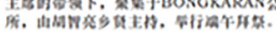

txis

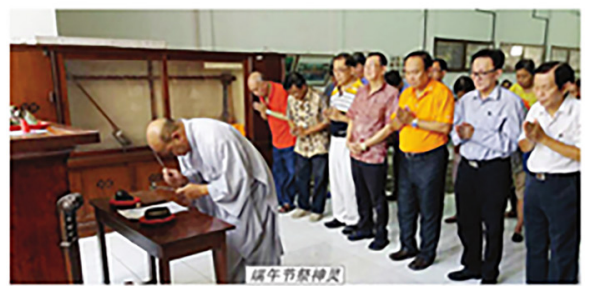

Figure 3. The coverage of Duanwu Jie in Qiandao Ribao's Huashe Dongtai Source: Qiandao Ribao (2017a)

Besides the activities of the various Chinese organisations, the celebration of Chinese traditions also receives wide coverage. While the Chinese New Year as the biggest celebration, which was declared a national holiday by President Megawati in 2001, is also covered by most other non-Chinese media, the coverage in the Chinese ethnic media is more intense and often includes the history behind the traditions and the rituals. They also report on how the ethnic Chinese in other parts of the world are celebrating but emphasise that no matter how global the Chinese New Year celebration is, the celebration in Indonesia has its own local flavour. For example, the local influence is seen in the special food the Chinese Indonesians prepare, such as Lontong Capgomeh (Suprajitno 2008). 
Through this kind of coverage, the Chinese ethnic media seeks to build an image that the ethnic Chinese in Indonesia are also a part of the world-wide Chinese community, yet, at the same time, are also rooted in Indonesia. However, the emphasis on being part of the global Chinese community tends to imply that Chineseness and the Chinese identity are more important. Other Chinese rituals and traditions, such as Qingming, Duanwu Jie and Zhongqiu Jie, which the national newspapers often do not report, are also covered widely in the Chinese media, further exemplifying the importance the Chinese media places on Chinese traditions and rituals to promote Chineseness.

The Chinese media also focus on the tenets of Chinese culture as they consider themselves to be "one of the gatekeepers of Chinese culture" (Hoon 2006, 112). Chinese culture dominates Chinese media, with a great deal of space being devoted to cultural matters. Chinese culture feature articles such as Chinese cultural commentaries, Chinese traditions and Chinese classical stories are abundant in the Fukan (Supplement) section of all the Chinese newspapers. In addition to the Fukan section, Qiandao Ribao also devotes space to sections entitled Zhonghua Wenhua (Chinese Culture) and Shuhua Xinshang (Chinese Paintings and Calligraphy Appreciation).

The Chinese media also celebrates the Chinese language. For many Chinese Indonesians of older generation, namely, those who were born and grew up before the New Order era, the Chinese language is an important part of their Chinese identity and is seen as the quintessence of Chineseness. The rise of China in global politics has also contributed to the promotion of the Chinese language, which the Chinese Media claim is helping their goal. One director of a Chinese newspaper said that, "Chinese language has become a world trend because of the growing Chinese economy... Young Chinese Indonesians learn Mandarin for economic prospects. The search for roots will come later - after they learn about Chinese culture" (as quoted in Hoon 2006, 113). This statement clearly highlights the salience of ethnic language and culture as part of ethnicity and ethnic identity; that is, a Chinese who does not speak Chinese is considered to be losing their Chineseness. Ang (2001) noted that diasporic Chinese who do not speak Chinese are often questioned about the authenticity of their Chineseness. The promotion of the Chinese language is also reflected in the amount of space allocated to Chinese literature, short stories and poems in the media, as they believe that promoting Chinese language and culture can help develop the Chineseness of young Chinese Indonesians, which is why they provide specialised sections, such as Qiandao Ribao's Huawen Yuandi (Chinese Language Garden) or the Jakarta-based Guoji Ribao's Shisheng Yuandi (Teacher-Student Garden), in which students who learn Chinese can publish their compositions. 
The rise of China in world politics and the role of the global Chinese diaspora in the economy also reinforce the interest of Chinese Indonesians in China and their identity as part of the Chinese diasporic community. Their interest in their ancestral country and their identification as a Chinese diasporic community are reflected in the coverage of China and the Chinese diaspora, which provides not only information on fellow diasporic communities, but also highlights common points of reference. From this information, the "deterritorialised subjects", such as the Chinese Indonesian community can sustain their "cultural continuity" (Thompson 1995), which can serve to strengthen their ethnic identity further. The Chinese media gives them areas of cultural identification in special sections on China, Hong Kong and Taiwan so that they can imagine a coherent and continuous identity. Guoji Ribao, Qiandao Ribao and Yindunixiya Shangbao each has Zhongguo Yaowen (China News), Liang'an Side (Four Places across Taiwan Straits) and Zhonggangtai Xinwen (China, Hong Kong and Taiwan News), all of which cover issues in China, Hong Kong and Taiwan. Qiandao Ribao also has a section called Yinzhong Youhao (Indonesia-China Friendship) that highlights the friendship between Indonesia and China and covers various aspects from culture to economics. When asked why they had these special sections on the regions of China, Hong Kong and Taiwan rather than combining the news into the Guoji Xinwen (International News) section, some editors and senior journalists said that many Chinese Indonesians were eager to know news about the region because of China's economic prowess and its "special connection". One journalist told author,

China is an economic power house now. With its Maritime Silk Road and One-belt-one-road Initiatives, China could play an important role in the world's economy. It would be a loss for us to neglect China. (A journalist, pers. comm., 29th June 2017)

Elaborating what the "special connection" was, an editor said "Our ancestors came from China, so obviously, we have a special connection with the country, although we are now Indonesians" (Informant, pers. comm., 19th September 2017).

While mentioning the economic prowess of China, they emphasised the "special connection", which can also be seen in news coverage about China. For example, Guoji Ribao (2017b) gave the title "Zuguo de Mingtian Hui Geng Hao: Qingzhu Zhonghua Renmin Gongheguo Chengli Liushiba Zhounian Zhaodai Hui Ceji" (The Future of the Motherland Will be Better: Celebrating the 68th Year of the Founding of the People's Republic of China) for its coverage of China's national day. The choice of the words used for refereeing to China, that is zuguo (motherland), describe what the people behind the Chinese media think about the special connection. 
The Chinese media also reports news on Chinese diasporic communities, with most putting this news in the Huashe or Huashe Xinwen sections. The coverage is not only about activities and happenings in these diasporic communities, but also about the achievements of the members. Qiandao Ribao goes further by having a section called Tianxia Huaren (Chinese People in the World), which features successful people, as the paper wishes Chinese Indonesians to be inspired by these success stories. According to Hoon $(2006,109)$, this "assumes a (trans) nationalistic pride of belonging to the Chinese 'race', even though they are in different locations".

This global diasporic identification is also evident in the reporting of pop culture news. All Chinese-language and most Indonesian-language Chinese media cover oriental pop culture from China, Hong Kong and Taiwan, with Indonesian pop culture receiving little attention. Maybe this could be due to the huge popularity of Chinese pop culture; however, Chinese pop culture, as seen in the Chinese media, could be thought of as an expression of the desires of the Chinese community, at least those behind the Chinese media, to identify themselves with what they believe as their ethnic pop culture. Sinclair et al. $(2000,35)$ proved that television entertainment programs can generate a strong sense of belonging and identity. The consumption of Chinese pop culture could be seen as a reflection of "the epistephilic desire" of Chinese Indonesians for entertainment from "home" (Naficy 1993, 107). The media also often highlights the Chinese background of Indonesian entertainers, something that is rarely seen in the mainstream media.

The identification of Chinese Indonesians with other Chinese communities in other parts of the world in the Chinese media's coverage of news and events in China, in the Chinese diasporic communities and in the Chinese entertainment news, is all aimed at fostering a sense of Chineseness and Chinese identity. The Chinese media believe that this kind of coverage can generate the feeling in Chinese Indonesians that they share the same cultural beliefs and traditions as the Chinese communities worldwide and that they are part of an imagined diasporic Chinese community. This kind of coverage conveys an "image of their communion" with the Chinese diaspora (Anderson 2006, 6), which in the author's opinion, is central to the discourse in the Chinese media, as can be seen in the symbolic Chinese ethnic forms published daily.

Author's observations have also found that through the production of symbolic forms of ethnicity, the Chinese media aims to reconstruct the Chineseness in Chinese Indonesians that was decimated by the New Order, as stated by Huang 
on 12th June 2012. Explaining the idea behind the devotion of so much space to Chinese culture in his newspaper, one of the founding fathers of a newspaper said,

We adopted this idea because we hope that young Chinese Indonesians who do not know their language and culture can study them. We also hope that by studying them, they love their ethnic culture and develop their ethnic belonging. Like the saying goes, tak kenal maka tak sayang (Indonesian proverb which literally means, "You cannot love what you do not know). (Informant, pers. comm., 11th April 2017)

Author's findings on the Chinese media have illuminated how the media is trying to reinforce the ethnic identity of their audience by triggering emotional attachments to ethnic symbols, which then feeds into feelings of ethnicity and ethnic identity in the readers. The Chinese media employ symbolic forms of ethnic imagining by foregrounding a Chineseness that links Chinese Indonesians to the global Chinese diasporic community. However, it is not easy for the Chinese media to achieve their cultural mission, especially in the younger generation, as a wide gap exists between the older Chinese generation behind the media and the potential readers who come mostly from the younger generation. This occurs because of the heterogeneity of Chinese Indonesian community as a result of, among others, generational differences and different cultural orientations. The way the media presents their content might not be interesting to the younger generation of Chinese Indonesians, an idea that is discussed further in the following section.

\section{Imagined Nostalgia}

The coverage and exposure of the activities of Chinese organisations, language, culture and traditions has led to the emergence of Chineseness in the public sphere. In Habermasian terms, the public sphere is a cultural domain of social interaction in which the public concerned are carefully deliberated for furthering the critical knowledge that could produce change. Seen from this Habermasian perspective, the Chinese media advances their concerns regarding Chinese Indonesian ethnicity through the circulation and discussion of images, ideas and arguments about Chineseness. Using ethnic symbols in their publications that are of salience to the Chinese, the Chinese media are attempting to construct a Chinese identity. A chief editor of a Chinese newspaper says, "Chinese culture has a fine history of 5,000 years. Assimilated [Indonesianised] Chinese have lost this noble culture. They are notably [un-Chinese] in their personality, including their morals" (as quoted in Hoon 2006, 112). 
Hoon's $(2006,113)$ study also revealed that the Chinese media have tried to revive the Chinese culture that was lost during the New Order period. By exposing Chinese culture, they hope that the readers and especially young Chinese Indonesians, can come to understand their ancestral roots and cultural heritage and hopefully reaffirm their ethnicity because to quote Ong $(1999,169)$, "the overall framing of message (in Chinese ethnic media) suggests that the identity at stake is (Chinese Indonesian) subjects" who have been detached from their ethnic and cultural heritage. Therefore, the Chinese media is attempting to construct the Chineseness they think was lost because of the New Order policy.

Yet, as mentioned previously, there is a gap between the people and the Chinese media and it is therefore the potential readers who have become the "target" of their cultural mission. However, these potential readers have their own perceptions regarding China and Chinese culture, as exemplified by the following interviewees.

A 26-year-old shop-owner: Our generation is alienated from the more "sophisticated" Chinese culture. We know nothing about proper rituals, such as ancestor veneration. And I don't want to know about all those things. Too traditional. Even people in China do not practice them. (Informant, pers. comm., 19th July 2017)

A 35-year-old banker: Ancestor veneration is a typical Chinese ritual. It is intended to cultivate filial piety. But well, I don't think it is necessary for us to do that. Showing respect and filial piety to our parents when they are still alive is much better than venerating them when they have passed away. (Informant, pers. comm., 24th July 2017)

While they admitted that Chinese culture and traditional rituals were good, the two informants above thought that the Chinese culture and traditional rituals Chinese media reported in their news and coverage were far-fetched. They are not closely related to their daily lives. This was one reason why they were not interested in reading them, despite their good Chinese proficiency, as they used to study Chinese in China before. The people behind the Chinese media may not be aware that culture can change and so can those who practice them. Because of this, younger Chinese find that this kind of coverage is boring.

A 20-year-old college student majoring in Chinese: I like Qiandao Ribao's Huawen Yuandi. We can send our essays for publication there. It is like a space where we can practice our writing skills. It is the only part that I read. ... I skip reading other sections. They are boring. (Informant, pers. comm., 14th September 2017) 
Even those who have a connection with China, economic and otherwise, think that the news reports and coverage of Chinese media focus too much on China.

A 30-year-old businesswoman who often goes to China on business: Chinese newspapers are very China-centric. The coverage on China is too much, I think. I know that China is an economic super power, but it does not mean everything about China is news-worthy. (Informant, pers. comm., 11th September 2017)

A 29-year-old professional who pursued his master's degree in China: Too much coverage on China.... They [news reports and articles about China and diasporic Chinese] are not closely related to us. No point in reporting them extensively. (Informant, pers. comm., 5th December 2017)

The five younger Chinese Indonesians think that the Chinese media is unattractive because of their loose or even non-existent connections with China and their changing views on Chinese traditions and culture. While not all young Chinese Indonesians feel the same as the interviewees above, it is evident that not all young Chinese Indonesians share the common view of the older generation on China and Chinese culture. Therefore, the, coverage is unable to attract many young Chinese Indonesians. The editors and journalists at Qiandao Ribao and Guoji Ribao admitted that their readers' demographic profile was dominated by Chinese who had received a Chinese education and that their younger readers were mostly those who worked in fields related to the Chinese language (personal communication). While the symbolic forms of imagining encapsulated in the memories of the past may provide ethnic salience for the older generation, these same forms do not appear to carry a lot of weight with others such as the younger generation. In other words, the Chinese media overlooks the facts that Chinese Indonesians are diverse and this diversity leads to different interpretation of Chineseness. This is the reason the Chinese media is facing difficulties in carrying out their cultural mission to reconstruct the Chineseness in Chinese Indonesians they believe was lost during the New Order era.

However, author contends that this difficulty has occurred because in their efforts to indicate the degree or authenticity of Chineseness, the Chinese media have objectified Chinese culture by breaking it into practices, customs and traditions that carry symbolic weight and can be measured. Therefore, with this line of thought, some people are considered more Chinese because of their greater Chineseness and others are considered less Chinese because of their limited or lost Chineseness. This opinion identifies Chineseness as essential to ethnicity and also reflects a perception that Chinese culture is static and unchanging, which is not acceptable 
to the Chinese who grew up during the New Order era. In their effort to construct Chineseness through the use of Chinese cultural symbols and representations, the media have created an "imagined nostalgia" (Appadurai 1996, 77). The Chinese Indonesians behind the Chinese media may not be aware that younger Chinese Indonesians do not share their sentiments. Since the nostalgia they are highlighting is nostalgia for something that has never existed in the younger generations' lives, the media's Chineseness is unrelated to their lives because Chineseness shifts over time due to personal experience and social change. Donald Nonini and Aihwa Ong commented that Chineseness was no longer "a property or essence of a person calculated by that person's having more or fewer 'Chinese values' or norms". Instead, it should be seen in terms of the "multiplicity" (Nonini and Ong 1997, 13) of being Chinese as reflected in the Chinese Indonesian community. Therefore, the way the Chinese media treat Chinese ethnic symbols is beneficial in terms of public sphere awareness, but misguided since they feel that this version of Chineseness and Chinese identity is sacrosanct; however, personal experience and social change are essential elements for the construction of Chineseness and Chinese identity in modern Indonesia. In other words, this imagined nostalgia is not shared by the younger generation of Chinese Indonesians, who have or are developing their own sense of their Chineseness.

\section{Conclusion}

The demise of the New Order paved the way for the Chinese Indonesian community to establish their own media, the cultural mission of which has been to preserve their ethnic culture and identity and encourage a certain ethnic identity in the younger generation of Chinese Indonesians. The Chinese media strongly believes that its function is to reconstruct the Chineseness and Chinese identity that were lost in the three decades of the New Order.

The media's reconstruction of Chineseness and Chinese identity has attempted to reinforce the Chinese Indonesian community's imagining (perceptions and feelings) of their ethnicity through the use of ethnic symbols that are salient to the Chinese cultural consciousness, with the belief that ethnic (Chinese) symbols and representations can forge ethnicity (Chineseness) and that through these emotional attachments to shared ethnic (Chinese) symbols, the people (Chinese Indonesians) can perceive a belonging to one (Chinese) community.

The strategies the Chinese media have adopted in their use of ethnic symbols for identity reconstruction are clearly reflected in the media content. Through news reports, editorials, opinions and other features in their publications, they have sought to create an image of communion in the minds of the readers, with the hope 
that this frequent exposure can strengthen and maintain the imagined community. However, in their efforts, they have developed an "imagined nostalgia" that the younger generation of Chinese Indonesians may not share. Therefore, the media is trapped in an essentialism that negates the possibility of the multiple forms of Chineseness and the multiple expressions of modern Chinese identity that exist in the Chinese diasporic community. Therefore, in my opinion, although they have been successful in bringing back Chinese culture to the Indonesian public, at the moment, it is difficult to achieve their goal of reconstructing the Chinese identity for the young Chinese Indonesian generation because it is a version of Chinese identity based on an "imagined nostalgia" that is often unrelated to the reality of young Chinese Indonesians.

\section{References}

Anderson, B. 2006. Imagined communities: Reflections on the origin and spread of nationalism. New York: Verso.

Ang, I. 2001. On not speaking Chinese: Living between Asia and the West. New York: Routledge.

Appadurai, A. 1996. Modernity at large: Cultural dimensions of globalization. Minneapolis, MN: University of Minnesota Press.

Barth, F. 1969. Ethnic groups and boundaries: The social organization of culture difference. Long Grove, IL: Waveland Press.

Bayar, M. 2009. Reconsidering primordialism: An alternative approach to the study of ethnicity. Ethnic and Racial Studies 32(9): 1637-1657. https://doi. org/10.1080/01419870902763878

Bhavnani, R. and Miodownik, D. 2009. Ethnic polarization, ethnic salience and civil war. Journal of Conflict Resolution 53(1): 30-49. https://doi. org/10.1177/0022002708325945

Bowen, Z. 2017. Transversal communications and the boundaries of identification. Social Alternatives 36(1): 27-29.

Chua, B.H. 2006. Gossip about stars: Newspaper and pop culture China. In Media and the Chinese diaspora, ed. W. Sun, 75-90. New York: Routledge.

Cohen, A.P. 1985. The symbolic construction of community. New York: Tanistock Publications.

Coppel, C.A. 1983. Indonesian Chinese in crisis. Oxford: Oxford University Press.

Cornell, S. 1996. The variable ties that bind: Content and circumstance in ethnic processes. Ethnic and Racial Studies 19(2): 265-289. https://doi.org/10.1080/01419870.1996 .9993910

Dawis, A. 2007. Chinese language proficiency and the politics of identity. The Jakarta Post, 29 July.

Dayan, D. and Katz, E. 1992. Media events: The live broadcasting of history. Cambridge: Harvard University Press. 
Driedeger, L. 1989. The ethnic factor: Identity and diversity. New York: McGraw.

Eriksen, T.H. 2010. Ethnicity and nationalism: Anthropological perspectives (3rd ed.). New York: Pluto Press.

Fenton, S. 2010. Ethnicity (2nd rev. ed.). Malden, MA: Polity Press.

Gans, H.J. 2017. Another look at symbolic ethnicity. Ethnic and Racial Studies 40(9): 1410-1417. https://doi.org/10.1080/01419870.2017.1308527

Gillespie, M. 1995. Television, ethnicity and cultural change. New York: Routledge.

Guoji Ribao. 2018. 印尼华裔总会一行人会晤绕哈利大使 (Yinni Huayi Zonghui Yixing Ren huiwu Rao Hali Dashi), 13 April.

2017a. 师生园地 (Shisheng Yuandi), 31 May.

2017b. 祖国的明天会更好一庆祝中华人民共和国成立六十八周年招待会 侧记 (Zuguo de mingtian hui geng hao - Qingzhu Zhonghua Renmin Gongheguo chengli liushiba zhounian zhaodai hui ceji), 2 October.

Gupta, A. and Ferguson, J. 1992. Beyond "culture": Space, identity and the politics of difference. Cultural Anthropology 7(1): 6-23. https://doi.org/10.1525/ can.1992.7.1.02a00020

Habermas, J. 1991. The public sphere. In Rethinking popular culture: Contemporary perspectives in cultural studies, eds. C. Mukerji and M. Schudson, 398-404. Berkeley, CA: University of California Press.

Hall, S. 1996. Introduction: Who needs identity? In Questions of cultural identity, eds. S. Hall and P. du Gay, 1-17. Thousand Oaks, CA: SAGE Publications Inc.

Hoon, C. 2006. "A hundred flowers bloom": The re-emergence of the Chinese press in Post-Suharto Indonesia. In Media and the Chinese diaspora, ed. W. Sun, 91-118. New York: Routledge.

Jusuf, E.I. 2001. Jalan panjang penghapusan diskriminasi rasial. Jakarta: Solidaritas Nusa Bangsa.

Karni, A.S., Mulya, R. and Windrawan, P. 2006. Hajatan Tionghoa lintas agama. Gatra, 30 January-4 February. http://arsip.gatra.com/2006-01-30/majalah/artikel. php?pil=23\&amp;id=91914 (accessed 31 July 2018).

Kivisto, P. 2017. The origins of "New Assimilation Theories". Ethnic and Racial Studies 40(9): 1418-1429. https://doi.org/10.1080/01419870.2017.1300299

Kompas. 2008. Perkembangan sekolah Tionghoa di era Reformasi, 2 June.

2007. Beberapa gereja menyelenggarakan misa Imlek, 19 February.

Lie, A. 2017. Learning Chinese as a heritage language by two multilingual youths in Indonesia. In Educating Chinese-heritage students in the global-local nexus: Identities, challenges and opportunities, eds. G. Li and W. Ma, 47-65. London: Routledge.

Ma, E.K. 1999. Culture, politics and television in Hong Kong. New York: Routledge.

Matsaganis, M.D. 2011. Understanding ethnic media: Producers, consumers and cocieties. Thousand Oaks, CA: SAGE Publications Inc.

Naficy, H. 1993. The making of exile cultures: Iranian television in Los Angeles. Minneapolis, MN: University of Minnesota Press. 
Nonini, D.M. and Ong, A. 1997. Introduction: Chinese transnationalism as an alternative modernity. In Ungrounded empire: The cultural politics of modern Chinese transnationalism, eds. A. Ong and D.M. Nonini, 3-36. New York: Routledge.

Oh, D.C. 2016. Reconsidering ethnic media research: An argument for a diasporic identity framework. Atlantic Journal of Communication 24(5): 264-275. https://doi.org/10. 1080/15456870.2016.1232259

Ong, A. 1999. Flexible citizenship: The cultural logics of transnationality. Durham, NC: Duke University Press.

Pandiangan, A. 2003. Chinese press after the New Order: Caught between the continuity of idealism and the logic of the market. Asian Ethnicity 4(3): 401-419. https://doi. org/10.1080/1343900032000117222

Qiandao Ribao. 2017a. 祭端午添寿夫 一 记泗水广肇会馆举办端午节祭祀活动 $(\mathrm{Ji}$ Duanwujie Tian Shou Fu: Ji Sishui Guangzhao Huiguan Juban Duanwujie Jisi Huodong), 2 June.

. 2017b. 印尼华裔明星一姹姹・弗雷德里卡 (Yinni Huayi mingxing - Chacha Fuleidelika), 27 May.

2010.《千岛日报》创刊十周年有感 (“Qiandao Ribao”Chuanggan Shi Zhounian Yougan), 11 October.

Sinclair, J., Yue, A., Hawkins, G., Kee, P. and Fox, J. 2000. Chinese cosmopolitanism and media use. In Floating lives: The media and Asian diaspora, eds. J. Sinclair and S. Cunningham, 35-90. St. Lucia, Australia: University of Queensland Press.

Smajda, J. and Gerteis, J. 2012. Ethnic community and ethnic boundaries in a "saucescented neighbourhood". Sociological Forum 27(3): 617-640. https://doi. org/10.1111/j.1573-7861.2012.01338.x

Somani, I.S. and Guo, J. 2018. Seeing Indian, being Indian: Diaspora, identity and ethnic media. Howard Journal of Communications 29(1): 63-82. https://doi.org/10.1080/ 10646175.2017.1327376

Suprajitno, S. 2008. Capgomeh: The localization of Chinese culture. The Jakarta Post, 25 February.

Suryadinata, L. 1997. Ethnic Chinese in Southeast Asia: Overseas Chinese, Chinese overseas, or Southeast Asian? In Ethnic Chinese as Southeast Asians, ed. L. Suryadinata, 1-24. Singapore: Institute of Southeast Asian Studies (ISEAS).

Thompson, J.B. 1995. The media and modernity: A social theory of the media. Stanford, CA: Stanford University Press.

Turner, S. and Allen, P. 2007. Chinese Indonesians in a rapidly changing nation: Pressures of ethnicity and identity. Asia Pacific View Point 48(1): 112-127. https://doi. org/10.1111/j.1467-8373.2007.00334.x

Weeks, J. 1990. The value of difference. In Identity: Community, culture, difference, ed. J. Rutherford, 88-100. London: Lawrence \& Wishart Ltd.

Wimmer, A. 2008. The making and unmaking of ethnic boundaries: A multilevel process theory. American Journal of Sociology 113(4): 970-1022. https://doi. org/10.1086/522803 
Yindunixiya Shangbao. 2018. 印尼萧氏宗亲总会春节团拜晚会今年承办“第11届 环球萧氏宗亲恳亲大会” (Yinni Xiao Shi Zongqin Zonghui Chunjie Tuanbai Wanhui Jinnian chengban "Di 11 Jie Huanqiu Xiao Shi Zongqin Ken Qin Dahui"), 28 February. http://old.shangbaoindonesia.com/?p=207650 (accessed 6 August 2018).

Yu, S.S. 2018. Multi-ethnic public sphere and accessible ethnic media: Mapping online English-language ethnic media. Journal of Ethnic and Migration Studies 44(11): 1976-1993. https://doi.org/10.1080/1369183X.2017.1346466 